\title{
Non-proteinaceous complexes III and IV mimicking electron transfer in the mitochondrial respiratory chain
}

\author{
Iago A. Modenez ${ }^{1}$, Lucyano J. A. Macedo ${ }^{1}$, Antonio F. A. A. Melo ${ }^{2}$, Andressa R. Pereira ${ }^{4}$, Osvaldo N.
} Oliveira, Jr. ${ }^{4}$, Frank N. Crespilho ${ }^{1 *}$.

\author{
${ }^{1}$ São Carlos Institute of Chemistry, University of São Paulo, São Carlos 13560-970, São Paulo, Brazil. \\ ${ }^{2}$ Federal Institute of Education, Science and Technology of Piauí, Teresina 64000-040, Piauí, Brazil. \\ ${ }^{4}$ São Carlos Institute of Physics, University of São Paulo, São Carlos 13560-590, São Paulo, Brazil. \\ *Correspondence to: frankcrespilho@iqsc.usp.br
}

\begin{abstract}
Synthetic biology pursues the understanding of biological processes and their possible mimicry with artificial bioinspired materials. We explore the redox properties of magnetic iron oxide nanoparticles to mimic the redox activity of complexes III and IV towards cytochrome c. We demonstrate that these nanoparticles, incorporated as non-proteinaceous complexes III and IV in a mitochondrial cell membrane model, catalyze electron transfer similarly to natural complexes. The associated molecular mechanism was experimentally proven in solution and in a LangmuirBlodgett film; the protein-nanoparticle interactions are governed mainly by electrostatic forces, followed by electron transfer between the iron sites of the nanoparticles and the heme group. This work presents the first experimental demonstration that inorganic nanostructured systems may behave as proteins in the cell membrane.
\end{abstract}

Keywords: Biomimetic material, Cytochrome c, Iron oxides nanoparticles, Direct electron transfer, Mitochondrial cell membrane model. 


\section{INTRODUCTION}

Processes involving electron transfer (ET) reactions are essential for living organisms' cellular respiration and energy acquisition (1). The mitochondrial respiratory chain in eukaryotic cells is one significant example of biological ET, which consists of a series of electron-carrying membrane-embedded proteins whose electron transport is facilitated by a small soluble redox protein, referred to as cytochrome c (Cyt c) (2). Cytochromes, in general, play crucial roles in ET associated with energy metabolisms and in apoptosis (3). In the mitochondrial respiratory chain, the electron received by Cyt c from complex III derives from ubiquinol, and it is later transferred from Cyt c to complex IV, which eventually catalyzes the complete reduction of molecular oxygen to water. The interaction of Cyt $\mathrm{c}$ with these complexes is governed by long-range electrostatic interactions in addition to specific non-polar forces surrounding the heme crevice(4).

The design of biomimetic materials has triggered research in synthetic biology $(5,6)$, with molecules such as proteins, lipids, and DNA, associated with artificial components, used to mimic life processes and design biological systems nonexistent in nature (7). Iron oxides are promising inorganic materials for synthetic biology due to their abundance and ubiquity in the environment as a redox mediator in microbial cellular metabolism $(8,9)$. Electron exchange usually occurs across the cell membrane and iron-based oxides interface, promoted by cellular heme-containing c-types cytochrome proteins (10-12).

Magnetite $\left(\mathrm{Fe}_{3} \mathrm{O}_{4}-\mathrm{NPs}\right)$ and maghemite $\left(\gamma-\mathrm{Fe}_{2} \mathrm{O}_{3}-\mathrm{NPs}\right)$ are iron oxides differing only by $\mathrm{Fe}^{2+}$ cationic vacancies in their unit cells, i.e., $\mathrm{Fe}_{3} \mathrm{O}_{4}-\mathrm{NPs}$ contain $\mathrm{Fe}^{2+}$ and $\mathrm{Fe}^{3+}$ in a 1:2 stoichiometric ratio, while $\gamma-\mathrm{Fe}_{2} \mathrm{O}_{3}-\mathrm{NPs}$ contain only $\mathrm{Fe}^{3+}$. These nanoparticles have been used in biomedical and technological applications; for instance, $\mathrm{Fe}_{3} \mathrm{O}_{4}-\mathrm{NPs}$ may be classified as nanozymes due to their intrinsic peroxidase-like activity, catalyzing oxidation reactions similarly to active iron sites within the heme group of enzymes (12). Since ET reactions involving $\mathrm{Fe}_{3} \mathrm{O}_{4}$ $\mathrm{NPs} / \gamma-\mathrm{Fe}_{2} \mathrm{O}_{3}$-NPs and proteins have been reported (14), we hypothesize that these materials are able to mimic the activity of complexes III and IV towards Cyt c. Herein, we show a bioinspired system of one catalytic step in the mitochondrial respiratory chain based on the direct ET between iron oxides nanoparticles and Cyt c, as depicted in Fig. 1. Additionally, we elucidate the nanoparticle-protein ET mechanism at a molecular scale and provide the basis for the development of a novel class of biomimetic model materials. 


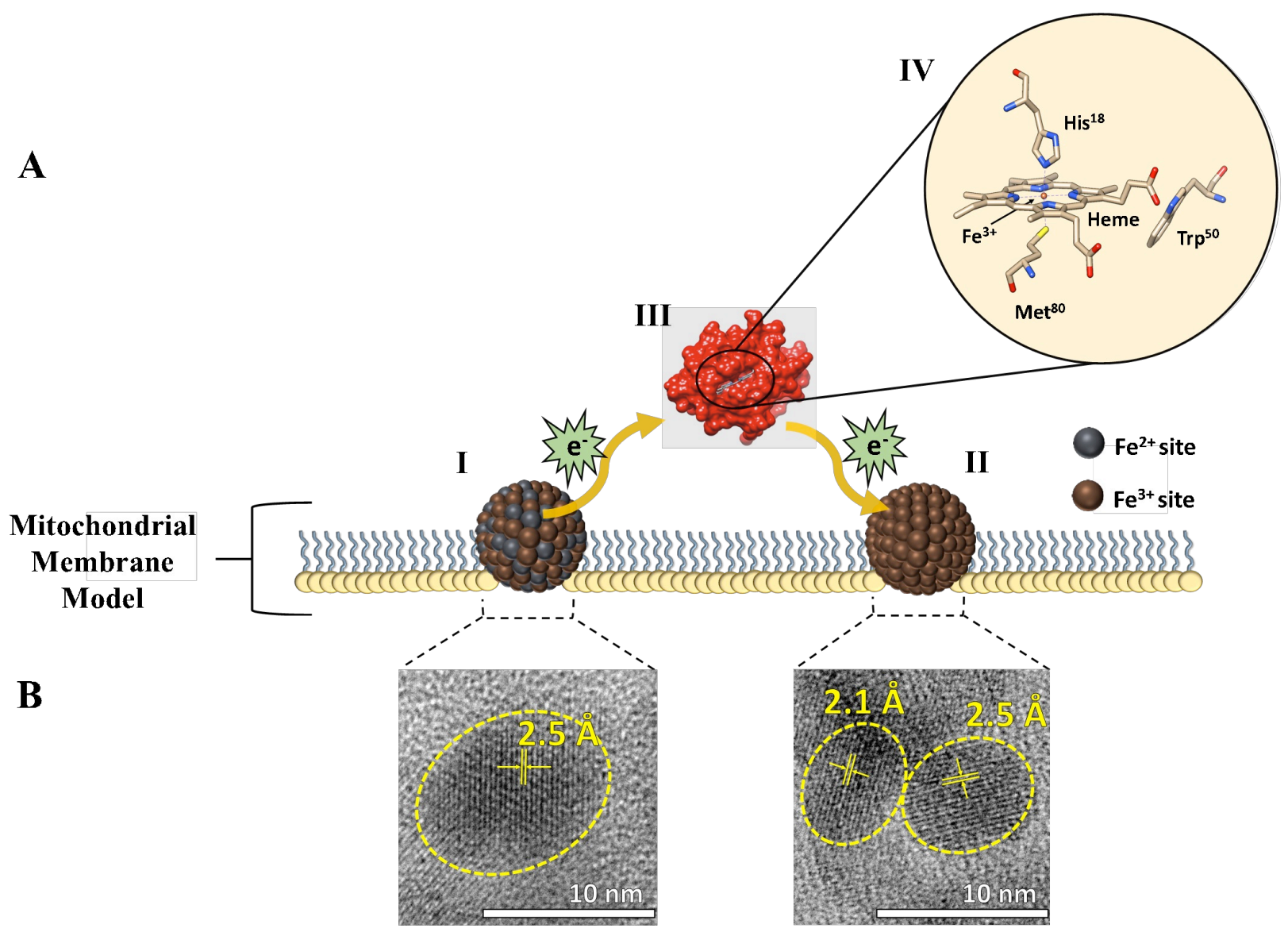

Fig. 1. Representation of the biomimetic membrane model. (A) $\mathrm{Fe}_{3} \mathrm{O}_{4}-\mathrm{NPs}$ (I) and $\gamma$ - $\mathrm{Fe}_{2} \mathrm{O}_{3}-\mathrm{NPs}_{\text {(II) }}$ incorporated in a monolayer mitochondrial cell membrane model. The Cyt c protein (III) - not incorporated in the membrane - has a heme group (IV) in which the iron changes between $\mathrm{Fe}^{3+}$ and $\mathrm{Fe}^{2+}$ in redox reactions; (B) TEM images indicate crystalline $\mathrm{Fe}_{3} \mathrm{O}_{4}-\mathrm{NPs}$ and $\gamma$ - $\mathrm{Fe}_{2} \mathrm{O}_{3}-\mathrm{NPs}$ with average sizes of $10 \pm 3$ $\mathrm{nm}$ and $11 \pm 3 \mathrm{~nm}$, respectively. The $2.5 \AA$ and $2.1 \AA$ lattice fringes shown in the TEM images correspond to the (311) and (400) planes of the crystalline structure, respectively.

\section{MATERIALS AND METHODS}

\section{Materials}

The materials used were ferric chloride hexahydrate $\left(\mathrm{FeCl}_{3} .6 \mathrm{H}_{2} \mathrm{O}\right.$, Sigma-Aldrich, $\left.99 \%\right)$, ferrous chloride tetrahydrate $\left(\mathrm{FeCl}_{2} .4 \mathrm{H}_{2} \mathrm{O}\right.$, Sigma-Aldrich, $\left.99 \%\right)$, hydrochloric acid ( $\mathrm{HCl}$, Sigma-Aldrich, $37 \%)$, sodium hydroxide $(\mathrm{NaOH}$, Synth, $98 \%)$, bovine heart cytochrome c (Sigma-Aldrich, purity $\geq 95 \%$, CAS Number: 9007-43-6), Sephadex ${ }^{\circledR}$ G-75 superfine (Sigma-Aldrich), sodium phosphate dibasic $\left(\mathrm{Na}_{2} \mathrm{HPO}_{4}\right.$, Synth, 98\%), potassium dihydrogen phosphate $\left(\mathrm{KH}_{2} \mathrm{PO}_{4}\right.$, Synth, 98\%), 
potassium chloride (KCl, Synth, 99\%), sodium chloride ( $\mathrm{NaCl}$, Synth, 99\%), nitric acid $\left(\mathrm{HNO}_{3}\right.$, Vetec, 65\%), ferric nitrate $\left(\mathrm{Fe}\left(\mathrm{NO}_{3}\right)_{3}\right)$, Sigma-Aldrich, 98\%), epoxy resin (Brascola), 1,1',2,2'tetramyristoyl cardiolipin (CL, Avanti Polar Lipids, 99\%), 1,2-dipalmitoyl-sn-glycero-3phosphoethanolamine (DPPE, Avanti Polar Lipids, 99\%), 1,2-dipalmitoyl-sn-glycero-3phosphocholine (DPPC, Sigma-Aldrich, 99\%), HPLC-grade chloroform ( $\mathrm{CHCl}_{3}$, Panreac, 99.9\%). The solutions were prepared using ultrapure water provided by a Milli-Q system from Millipore (resistivity $18.2 \mathrm{M} \Omega \mathrm{cm}$ ).

\section{$\mathrm{Fe}_{3} \mathrm{O}_{4}$ nanoparticles synthesis and characterization}

Magnetite nanoparticles $\left(\mathrm{Fe}_{3} \mathrm{O}_{4}-\mathrm{NPs}\right)$ were synthesized by co-precipitation as reported in the literature (15). To do so, $\mathrm{FeCl}_{3} \cdot 6 \mathrm{H}_{2} \mathrm{O}(5.4 \mathrm{~g})$ and $\mathrm{FeCl}_{2} \cdot 4 \mathrm{H}_{2} \mathrm{O}(2.0 \mathrm{~g})$ were dissolved in a deaerated $10 \mathrm{mmol} \mathrm{L}-1 \mathrm{HCl}$ solution $(25 \mathrm{~mL})$. Under a $\mathrm{N}_{2}$ saturated atmosphere, a deaerated $1.5 \mathrm{~mol} \mathrm{~L}^{-1}$ $\mathrm{NaOH}$ solution $(250 \mathrm{~mL})$ was added dropwise to the $\mathrm{Fe}^{3+} / \mathrm{Fe}^{2+}$ mixture with vigorous stirring at $80{ }^{\circ} \mathrm{C}$ to generate the magnetite nanoparticles (Equation 1). After approximately 30 min under stirring, the nanoparticles in suspension were separated with a magnet and continuously washed with deionized water until neutral $\mathrm{pH}$. Finally, a stock suspension $\left(5 \mathrm{mg} \mathrm{mL} \mathrm{m}^{-1}\right)$ was prepared dispersing the $\mathrm{Fe}_{3} \mathrm{O}_{4}-\mathrm{NPs}$ in a $5 \mathrm{mmol} \mathrm{L}^{-1}$ phosphate buffer saline (PBS) buffer (pH 7.4).

$$
2 \mathrm{Fe}^{3+}{ }_{(\mathrm{aq})}+\mathrm{Fe}^{2+}{ }_{(\mathrm{aq})}+8 \mathrm{OH}_{(\mathrm{aq})}^{-} \rightarrow \mathrm{Fe}_{3} \mathrm{O}_{4(\mathrm{~s})}+4 \mathrm{H}_{2} \mathrm{O}_{(\mathrm{l})}
$$

Transmission electron microscopy (TEM) images were acquired using a JEOL JEM-2100 operating at $200 \mathrm{kV}$. The sample was prepared dropping a diluted nanoparticle suspension on a 400-mesh cupper grid coated with lacey carbon film and then drying it under vacuum. The average size and polydispersity were determined using ImageJ software based on a count of 150 nanoparticles. X-ray powder diffraction pattern (XRD) data were obtained using a Bruker D8 Advanced diffractometer with $\mathrm{Cu} \mathrm{K}_{\alpha}(\lambda=1.5406 \AA)$ radiation. The scanning angle varied between $25^{\circ}<2 \theta<100^{\circ}$ with a scanning rate of $0.02^{\circ}$ each $10 \mathrm{~s}$. The average particle diameter was calculated based on the three most intense peaks (311), (511) and (440) using Scherrer's equation $(D=\mathrm{K} \lambda /(B \cos \theta))$, where $\mathrm{K}$ is the crystalline-shape factor (ca. 0.9 for spherical particles), $\lambda$ is the wavelength of the X-ray radiation, $B$ is the full-width at half-maximum of the X-ray diffraction peak and $\theta$ is the Bragg angle (16). The Fourier-transform infrared (FTIR) spectra were recorded 
in a Bruker Vertex 70v spectrometer using the transmission mode (1 mg of lyophilized protein and $99 \mathrm{mg}$ of $\mathrm{KBr}$ ) in the region of $4000-450 \mathrm{~cm}^{-1}$. Each spectrum was obtained by averaging 32 interferograms at a $4 \mathrm{~cm}^{-1}$ resolution using DLaTGS (Deuterated Lanthanum L-alanine doped Triglycine Sulphate) detector. The Zeta potential $(\zeta)$ and Dynamic Light Scattering (DLS) measurements were performed on a Zetasizer Nano Series Malvern instrument at $25^{\circ} \mathrm{C}$. $\mathrm{A} \mathrm{Fe}_{3} \mathrm{O}_{4}$ NPs suspension was prepared $\left(0.1 \mathrm{mg} \mathrm{mL}^{-1}\right)$ in PBS buffer $5 \mathrm{mmol} \mathrm{L}^{-1}$ (pH 7.4) and, then, filtered using $0.2 \mu \mathrm{m}$ pore sized membranes in order to remove any impurity before the measurements. The reported data were averaged over 3 accumulations.

\section{Cytochrome c structural characterization}

Cytochrome c was chromatographically purified using a Sephadex G-75 superfine matrix with PBS buffer $5 \mathrm{mmol} \mathrm{L}^{-1}(\mathrm{pH}$ 7.4) as eluent. All protein solutions were prepared in PBS buffer 5 $\mathrm{mmol} \mathrm{L}^{-1}$ (pH 7.4). Spectroscopy measurements in ultraviolet/visible region (UV-vis) were performed using a spectrophotometer Jasco V-760 between 200 and $700 \mathrm{~nm}$ with a quartz microcuvette $(1.0 \mathrm{~cm}$ optical path length). The cytochrome $\mathrm{c}$ solution was prepared in a concentration of $81 \mu \mathrm{mol} \mathrm{L}{ }^{-1}$. Circular Dichroism (CD) spectra were recorded on a Jasco J-815 spectropolarimeter in the range of 210 to $500 \mathrm{~nm}$ with an averaged data over 10 accumulations at $25^{\circ} \mathrm{C}$ using a cell of $1.0 \mathrm{~cm}$ optical path length. The sample solutions were prepared in a concentration of $10 \mu \mathrm{mol} \mathrm{L}^{-1}$ and the spectra were deconvoluted using CDNN software. FTIR spectra were recorded in a Bruker Vertex 70v spectrophotometer in the attenuated total reflectance (ATR) mode equipped with a single-bounce diamond crystal and a DLaTGS (Deuterated Lanthanum L-alanine doped Triglycine Sulphate) detector. The sample was dropped (10 $\mu \mathrm{L}$ of an $81 \mu \mathrm{mol} \mathrm{L}{ }^{-1}$ cytochrome c solution) and dried on the crystal and the spectra were recorded in the region $3800-380 \mathrm{~cm}^{-1}$ at a resolution of $4 \mathrm{~cm}^{-1}$ with an average data over 32 accumulations for each spectrum. The amide I region (1700-1600 $\mathrm{cm}^{-1}$ ) was deconvoluted using the second order derivative and the main bands were assigned according to the literature (17): 1658-1650 $\mathrm{cm}^{-1}(\alpha-$ helix), 1642-1624 $\mathrm{cm}^{-1}$ ( $\beta$-sheet) and 1690-1666 $\mathrm{cm}^{-1}$ ( $\beta$-turn). Zeta potential $(\zeta)$ and DLS measurements were performed in the same conditions as described in the previous section. Both $\mathrm{Fe}_{3} \mathrm{O}_{4}$-NPs and cytochrome c suspensions were prepared in a concentration of $0.1 \mathrm{mg} \mathrm{mL}^{-1}$ and mixed in a 1:1 proportion for the $\mathrm{Fe}_{3} \mathrm{O}_{4}-\mathrm{NPs}-\mathrm{Cyt} \mathrm{c}$ system analysis. The cyt $\mathrm{c}$ residual charge was calculated using ProtParam software from an amino acids sequence analysis. 


\section{Adsorption measurements}

The adsorption measurements were carried out to determine the equilibrium distribution of cyt $\mathrm{c}$ in solution and on nanoparticles, which was done by taking the decrease in UV-vis absorption of the protein. Since the contact between $\mathrm{Fe}_{3} \mathrm{O}_{4}$-NPs and oxidized cytochrome c (ferricytochrome c) leads to reduction of the protein and then to a different absorption spectrum, its concentration in solution was probed using the aromatic band at $280 \mathrm{~nm}$. We assume that reduction does not cause significant change in conformation or arrangement of the polypeptide chain (18). The measurements were carried out in a spectrophotometer Jasco V-760 from 200 to $700 \mathrm{~nm}$, with a quartz microcuvette $(1.0 \mathrm{~cm}$ optical path length), using a fixed concentration of cyt c $(10 \mu \mathrm{mol} \mathrm{L}-$ ${ }^{1}$ in PBS buffer $5 \mathrm{mmol} \mathrm{L}^{-1} \mathrm{pH}$ 7.4) and $\mathrm{Fe}_{3} \mathrm{O}_{4}$-NPs $\left(432 \mu \mathrm{mol} \mathrm{L}^{-1}\right)$. The mixture was continuously shaken, and the decrease in protein concentration was monitored through time.

\section{Steady-state fluorescence measurements}

The data were collected in a Hitachi F-4500 spectrofluorimeter with a $1.0 \mathrm{~cm}$ optical path length at three temperatures $\left(15,25\right.$ and $\left.35^{\circ} \mathrm{C}\right)$. The excitation and emission slits were set at $5.0 \mathrm{~nm}$ and the spectra were recorded in a wavelength range of 330-370 nm with a scanning rate of $240 \mathrm{~nm}$ $\min ^{-1}$. Fluorescence emission was measured upon exciting a $40 \mu \mathrm{mol} \mathrm{L}^{-1}$ cytochrome $\mathrm{c}$ solution at $300 \mathrm{~nm}$ in the presence of various $\mathrm{Fe}_{3} \mathrm{O}_{4}$ nanoparticles concentrations $(216,259,345,432,864$ and $1296 \mu \mathrm{mol} \mathrm{L}^{-1}$ ). The reference spectra were taken solely with PBS buffer and $\mathrm{Fe}_{3} \mathrm{O}_{4}-\mathrm{NPs}$, since the nanoparticles do not absorb light at the wavelength region under study. Their effect in the fluorescence analysis is negligible. The quenching mechanism was determined using SternVolmer equation (19) (Equation 2).

$$
F_{0} / F=1+K_{\text {sv }} c Q
$$

where $F_{0}$ and $F$ are the fluorescence intensities of the protein in the absence and presence of the quencher $Q$, respectively, $K_{\mathrm{sv}}$ is the Stern-Volmer quenching constant and $c Q$ is the quencher concentration. The bimolecular quenching constant $\left(K_{\mathrm{q}}\right)$ was calculated from Equation 3.

$$
K_{\mathrm{sv}}=K_{\mathrm{q}} \tau_{0}
$$


where $\tau_{0}$ is the average bimolecular fluorescence lifetime in the absence of the quencher, taken as $10^{-8} \mathrm{~s}(20,21)$. The number of binding sites per protein molecule $(n)$ and the binding constant $\left(K_{\mathrm{b}}\right)$ were calculated using Equation 4 (19).

$$
\log \left(\left(F_{0}-F\right) / F\right)=\log K_{\mathrm{b}}+n \log c Q
$$

(Equation 4)

\section{Kinetic and Thermodynamic parameters}

The ferricytochrome c reduction by $\mathrm{Fe}_{3} \mathrm{O}_{4}-\mathrm{NPs}$ was studied using in situ UV-visible absorption spectroscopy. All the protein solutions were prepared in PBS buffer $5 \mathrm{mmol} \mathrm{L}^{-1}$ (pH 7.4). The data were collected using a spectrophotometer Jasco V-760 with a quartz microcuvette $(1.0 \mathrm{~cm}$ optical path length). In order to determine the kinetic parameters, the reactions were carried out in a pseudo-first order regime, where the $\mathrm{Fe}_{3} \mathrm{O}_{4}-\mathrm{NPs}$ were in excess compared with ferricytochrome $\mathrm{c}$. The parameters were evaluated by fixing the ferricytochrome c solution concentration $(10 \mu \mathrm{mol} \mathrm{L}-$ $\left.{ }^{1}\right)$ and varying the nanoparticles concentration (108, 216, 432, and $864 \mu \mathrm{mol} \mathrm{L}^{-1}$ ) at four temperatures $\left(25,30,35\right.$ and $\left.40^{\circ} \mathrm{C}\right)$. The equipment was set to perform absorbance $(A)$ measurements each $10 \mathrm{~s}$ at a fixed wavelength $(550 \mathrm{~nm})$, corresponding to the formation of reduced cyt c. Owing to the excess of $\mathrm{Fe}_{3} \mathrm{O}_{4}-\mathrm{NPs}$, it is possible to assume that their concentration is constant throughout the reaction. So, one can obtain the apparent pseudo-first order rate constant $\left(k_{\mathrm{obs}}\right)$ as follows (22) (Equation 5):

$$
v=k_{\mathrm{obs}}[C y t c]
$$

where $v$ is the reaction rate and $[C y t c]$ is the concentration of ferricytochrome c solution. $k_{\text {obs }}$ may be obtained by plotting $\ln \left(A_{\infty}-A\right)$ versus time $(t)$, which should result in a straight line with slope $\mathrm{k}_{\text {obs }}$. The second-order rate constant $(k)$ may be obtained correlating $k_{\text {obs }}$ with the $\mathrm{Fe}_{3} \mathrm{O}_{4}-\mathrm{NPs}$ concentration (22) (Equation 6), since:

$$
k_{\mathrm{obs}}=k\left[\mathrm{Fe}_{3} \mathrm{O}_{4}-\mathrm{NPs}\right]
$$


where $\left[\mathrm{Fe}_{3} \mathrm{O}_{4}-\mathrm{NPs}\right]$ is the concentration of $\mathrm{Fe}_{3} \mathrm{O}_{4}$ nanoparticles. The experiments were carried out in the dark and both in opened and inert atmosphere to eliminate any doubt about the influence of atmospheric oxygen.

The activation energy was calculated using the Arrhenius equation(23) (Equation 7), since plotting ln $k$ against $1 / T$ gives a straight line with a slope of $-E_{\mathrm{a}} / \mathrm{R}$. Activation parameters based on the transition state theory, such as $\Delta H^{\star}$ and $\Delta S^{\star}$, were calculated though the Eyring plot (Equation 8) relating $\ln (k / T)$ with $1 / T$, where the slope corresponds to $-\Delta H^{\ddagger} / \mathrm{R}$ and the $\mathrm{y}$-intercept corresponds to $\ln \left(\mathrm{k}^{\prime} / \mathrm{h}\right)+\Delta S^{\ddagger} / \mathrm{R}$, where $\mathrm{k}^{\prime}$ is the Boltzmann constant and $\mathrm{h}$ is the Planck constant (22).

$$
\begin{gathered}
k=\mathrm{Ae}^{(-E \mathrm{a} / \mathrm{R} T)} \\
\ln (k / T)=-\Delta H^{\ddagger} / \mathrm{R} T+\ln \left(\mathrm{k}^{\prime} / \mathrm{h}\right)+\Delta S^{\ddagger} / \mathrm{R}
\end{gathered}
$$

The thermodynamic parameters of interaction between cyt $\mathrm{c}$ and $\mathrm{Fe}_{3} \mathrm{O}_{4}-\mathrm{NPs}$ were investigated using the van't Hoff equation (24) (Equation 9), from which $\Delta H^{\circ}$ and $\Delta S^{\circ}$ are obtained. $\Delta G^{\circ}$ binding is calculated using the Gibbs-Helmholtz equation (Equation 10).

$$
\begin{gathered}
\ln K_{\mathrm{b}}=-\Delta H^{\circ} / \mathrm{R} T+\Delta S^{\circ} / \mathrm{R} \\
\Delta G^{\circ}=\Delta H^{\circ}-\mathrm{T} \Delta S^{\circ}
\end{gathered}
$$

\section{$\gamma-\mathrm{Fe}_{2} \mathrm{O}_{3}$ nanoparticles synthesis and characterization}

The maghemite nanoparticles $\left(\gamma-\mathrm{Fe}_{2} \mathrm{O}_{3}-\mathrm{NPs}\right)$ were synthesized with method reported in (25). An aliquot of $10 \mathrm{~mL}$ of a suspension of $\mathrm{Fe}_{3} \mathrm{O}_{4}$ nanoparticles was stirred for $10 \mathrm{~min}$ in a $4 \mathrm{~mol} \mathrm{~L}^{-1}$ nitric acid solution. The precipitate was magnetically separated, washed several times with deionized water, and mixed with a $0.1 \mathrm{~mol} \mathrm{~L}^{-1}$ ferric nitrate solution at $90{ }^{\circ} \mathrm{C}$ for $30 \mathrm{~min}$ (Equation 11). The brown precipitate (maghemite) was separated from the solution and washed several times with deionized water. Finally, a stock suspension of $5 \mathrm{mg} \mathrm{mL}{ }^{-1}$ was prepared dispersing the $\gamma-\mathrm{Fe}_{2} \mathrm{O}_{3}$ NPs in a 5 mmol L-1 PBS buffer (pH 7.4).

$$
2 \mathrm{Fe}_{3} \mathrm{O}_{4(\mathrm{~s})}+\mathrm{HNO}_{3(\mathrm{aq})} \rightarrow \gamma-3 \mathrm{Fe}_{2} \mathrm{O}_{3(\mathrm{~s})}+\mathrm{HNO}_{2(\text { (aq) }}
$$


Transmission electron microscopy (TEM) images were acquired using a JEOL JEM-2100 operating at $200 \mathrm{kV}$. The sample was prepared dropping a diluted suspension of nanoparticles on a 400 mesh cupper grid coated with lacey carbon film and then drying it under vacuum. The average size and polydispersity were determined using ImageJ software from 100 nanoparticles. X-ray powder diffraction pattern (XRD) data were obtained using a Bruker D8 Advanced diffractometer with $\mathrm{Cu} \mathrm{K} \alpha(\lambda=1.5406 \AA)$ radiation. The scanning angle varied between $25^{\circ}<2 \theta$ $<100^{\circ}$ with a scanning rate of $0.02^{\circ}$ each $10 \mathrm{~s}$. The average particle diameter was calculated based on the three most intense peaks (311), (511) and (440) using Scherrer's equation.

\section{Langmuir monolayers and Langmuir-Blodgett (LB) films}

The lipid solutions were used without further purification. Surface pressure measurements were performed with a Mini KSV Langmuir trough with a Wilhelmy plate made of filter paper as the pressure $(\pi)$ sensor. The spreading solutions were prepared by dissolving DPPC in chloroform, and CL and DPPE in a mixture of methanol and chloroform. First, we prepared one solution of 1.0 $\mathrm{mg} \mathrm{mL} \mathrm{m}^{-1}$ for each compound, and then the ternary lipid mixture was obtained by mixing appropriate volumes of respective stock solution, using a molar fraction of 0.50:0.30:0.20 (DPPC:DPPE:CL), which corresponds to the composition of the mitochondrial membrane, referred to as DPPC-DPPE-CL. The aqueous subphase consisted of PBS buffer (pH 7.4) prepared in ultrapure water in absence and in the presence of a mixture of either $\mathrm{Fe}_{3} \mathrm{O}_{4}$ or $\gamma-\mathrm{Fe}_{2} \mathrm{O}_{3}$ nanoparticles. The lipid mixture dissolved in chloroform or in the mixture of methanol/chloroform was spread over the subphase surface with a Hamilton microsyringe. The time for solvent evaporation and the interaction between the lipids and the nanoparticles were $10 \mathrm{~min}$, and the monolayers were compressed with two symmetric moving barriers at a compression rate of $10 \mathrm{~cm}^{2}$ $\min ^{-1}$. The surface-pressure measurements were carried out at $22 \pm 1^{\circ} \mathrm{C}$ and repeated at least three times to ensure reproducibility. All experiments were performed in a class 10000 clean room. The Brewster angle microscopy (BAM) images for the Langmuir monolayers were acquired with an EP4 imaging ellipsometer from Accurion using an Ultraobjective at angles of incidence and view $53.1^{\circ}$, polarization at $2^{\circ}$, and analyzer at $10^{\circ}$. The images were geometrically corrected using the Data Studio software from Accurion. The equipment is coupled with a KSV trough, and therefore the images were taken while the Langmuir monolayers were being formed. 
The transfer of DPPC-DPPE-CL and DPPC-DPPE-CL-nanoparticles monolayers onto solid supports in the form of Langmuir-Blodgett (LB) films was performed at a constant surface pressure of $30 \mathrm{mN} \mathrm{m}^{-1}$, a temperature equals to $22 \pm 1^{\circ} \mathrm{C}$, and a deposition rate of $10 \mathrm{~mm} \mathrm{~min}^{-1}$. The supports used were glass (for the in situ UV-vis measurements) and ITO (for the electrochemical measurements). In all cases, a one-layer Y-type LB film was deposited with control of the transfer ratio during the upstroke. The LB film was allowed to dry for $30 \mathrm{~min}$., and then stored at $4{ }^{\circ} \mathrm{C}$ for later measurements. Polarization-modulation infrared reflection absorption spectroscopy (PM-IRRAS) was performed in the LB films using KSV PMI 550 instrument. In PM-IRRAS, an incoming light is modulated at high frequency between $s$ - and $p$-polarization, thus permitting the simultaneous measurement of the polarized reflectivities for the parallel and perpendicular directions to the plane of incidence. The experiments were performed at an incident angle of $81^{\circ}$, and an average of 9000 scans were collected for each spectrum at resolution of $8 \mathrm{~cm}^{-}$ 1. The PM-IRRAS spectrum of an ITO surface was used as background. Measurements were carried out in a class 10000 clean room at $22 \pm 1^{\circ} \mathrm{C}$.

\section{Electrochemical measurements}

The data were collected in an Autolab PGSTAT204 potentiostat/galvanostat (Metrohm). The experiments were performed using an electrochemical cell with three electrodes comprising of platinum plate as auxiliary electrode, a saturated $\mathrm{Ag} / \mathrm{AgCl}$ sat as the reference electrode, and as working electrode we used three ITO-based electrodes (indium tin oxide): one with only one-layer LB film (which will be referred to as LB film), another with a ferricytochrome $\mathrm{c}$ film on top of the one-layer LB film (referred to as LB film + Cyt c), and the third one with a ferricytochrome c film on top of the one-layer LB film with the incorporated nanoparticles (referred to as LB + NPs film + Cyt c). PBS buffer $0.1 \mathrm{~mol} \mathrm{~L}^{-1}$ (pH 7.4) was used as supporting electrolyte. Argon was purged for at least $30 \mathrm{~min}$ prior to recording the voltammograms at $25^{\circ} \mathrm{C}$ in a potential window from 0.4 $\mathrm{V}$ to $-0.2 \mathrm{~V}$ (vs Ag/ $\mathrm{AgCl}_{\text {sat }}$ ) at a $5 \mathrm{mV} \mathrm{s}^{-1}$ scan rate for ten cycles. The current in all electrochemical measurements was normalized by the geometric electrode area, resulting in a current density value $(j)$. 
In situ optical absorption spectroscopy

The data were collected in an AvaSpec-2048 (an Avantes spectrophotometer with Avalight-DHS deuterium-halogen light sources) using an optical-fiber module. The experiments were conducted in the dark with the set up shown in Figure 5c. First, a small region of the membrane on the glass was isolated using epoxy resin; after complete drying, $100 \mu \mathrm{L}$ of a concentrated ferricytochrome c solution $\left(810 \mu \mathrm{mol} \mathrm{L}^{-1}\right.$ in PBS buffer $\left.5 \mathrm{mmol} \mathrm{L}^{-1} \mathrm{pH} 7.4\right)$ were dropped on the isolated region. In situ absorption measurements were carried out at $25^{\circ} \mathrm{C}$ in the range between 350 and $600 \mathrm{~nm}$, with a spectrum taken every $20 \mathrm{~s}$ during $30 \mathrm{~min}$. The data were averaged over 200 accumulations at an integration time of $20 \mathrm{~ms}$.

\section{RESULTS AND DISCUSSION}

\section{$\mathrm{Fe}_{3} \mathrm{O}_{4}-\mathrm{NPs}$ as a biomimetic complex III}

Bare $\mathrm{Fe}_{3} \mathrm{O}_{4}$-NPs were synthesized via co-precipitation $(26,27)$ (Fig. S1, S2). In the presence of oxidized Cyt c, ET from $\mathrm{Fe}_{3} \mathrm{O}_{4}$-NPs to the protein occurs spontaneously, leading to a reduction of the heme group. The UV-vis absorption spectra of oxidized and reduced Cyt c states - also known as ferricytochrome c (ferricyt c) and ferrouscytochrome c (ferrouscyt c), respectively - in Fig. 2A, B feature typical protein absorption bands in the UV region (28). For hemeproteins such as Cyt c these include a band at $409 \mathrm{~nm}$ (Soret band), a shoulder at $356 \mathrm{~nm}$, and a weak band at $530 \mathrm{~nm}$ (Q band) due to the protein porphyrin chromophore. Shifts in Soret and Q bands are related to changes in the oxidation state of the iron ion in the heme group. Therefore, these differences in the spectroscopic signatures of Cyt $\mathrm{c}$ are useful for probing protein reduction. After the addition of $\mathrm{Fe}_{3} \mathrm{O}_{4}-\mathrm{NPs}$ to the ferricytochrome $\mathrm{c}$ solution, the Soret band and the shoulder shifted to $415 \mathrm{~nm}$ and $315 \mathrm{~nm}$, respectively, while the band at $530 \mathrm{~nm}$ split into two well-defined bands at $520 \mathrm{~nm}$ and $550 \mathrm{~nm}$ (Fig. 2A, B, red). These spectroscopic changes may also be associated with conformational rearrangements in the heme microenvironment (29) with the iron modified from hexacoordinated in ferricytochrome $\mathrm{c}$ to pentacoordinated in ferrouscytochrome $\mathrm{c}$ due to the rupture of the Fe-S(Met) bond (Fig. 2C). 

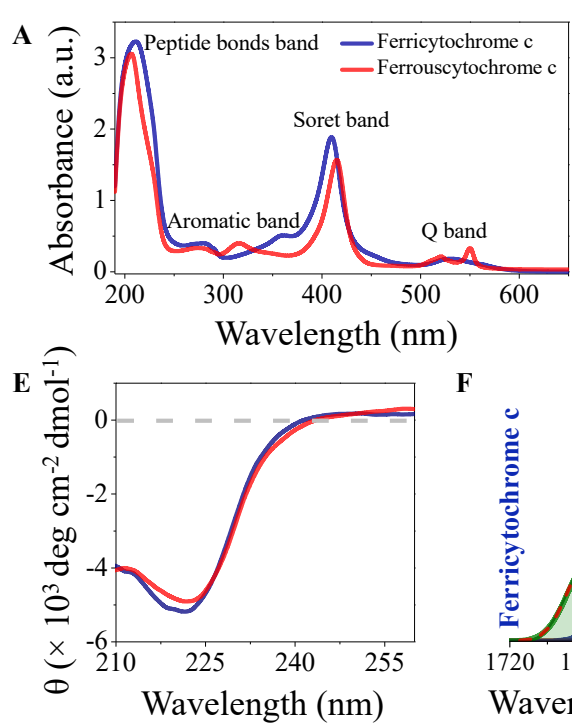

F
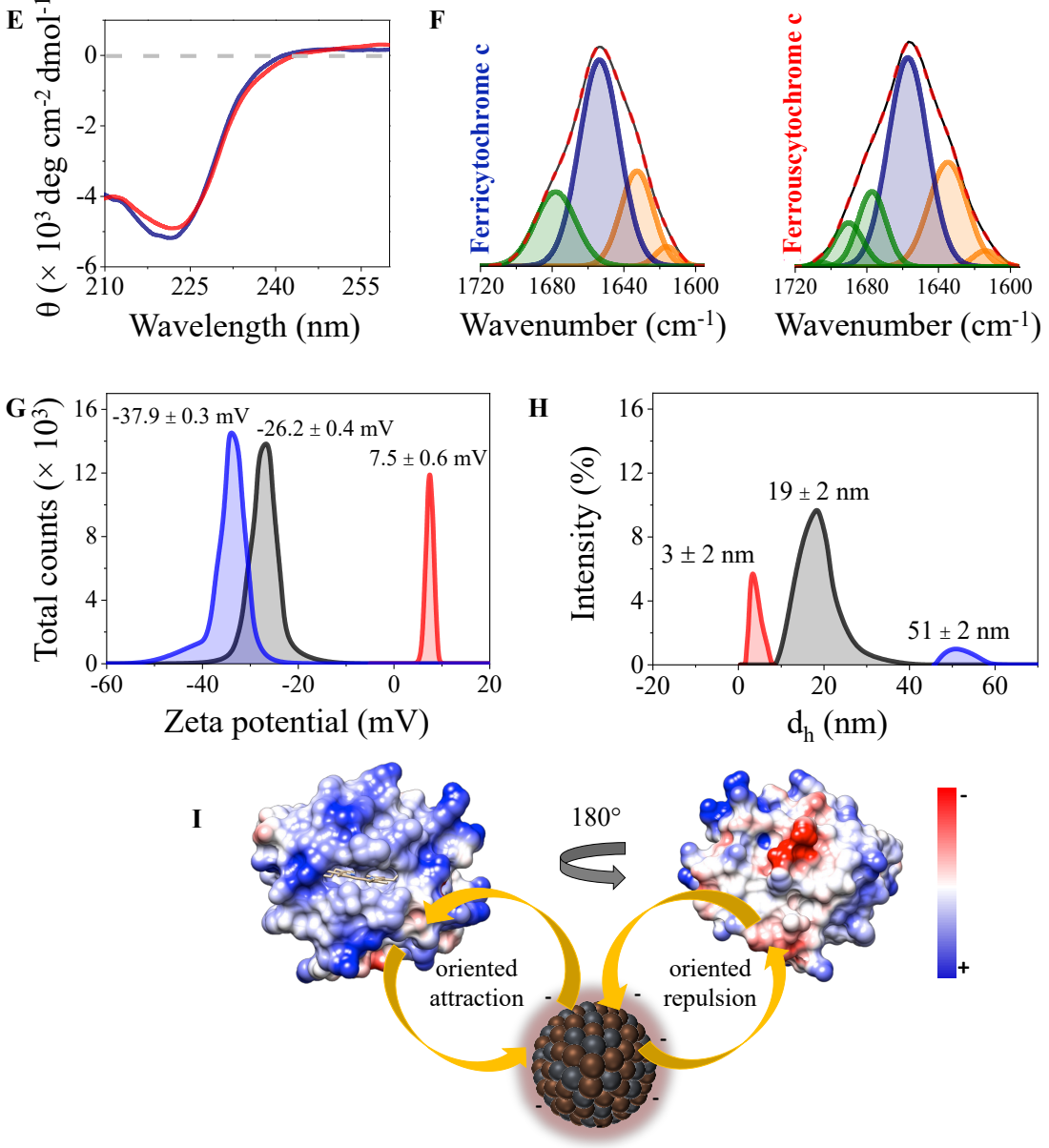

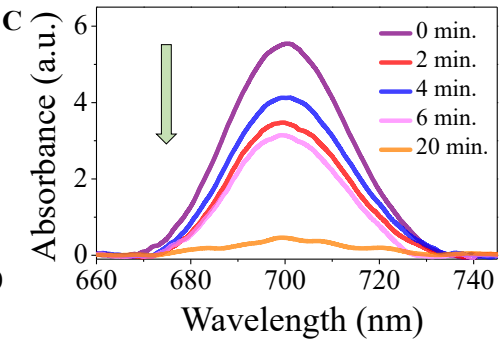

D

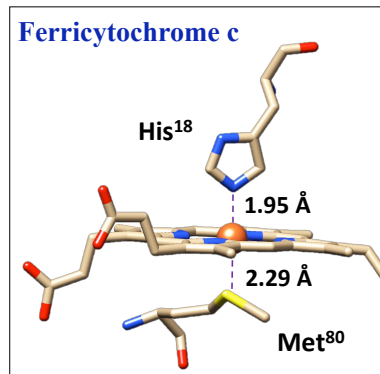

Ferrouscytochrome c

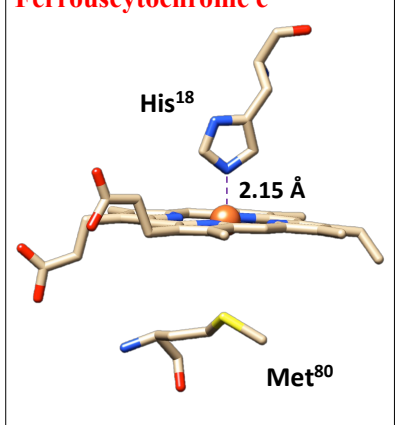

Fig. 2. $\mathrm{Fe}_{3} \mathrm{O}_{4}$-NPs and ferricytochrome c ET. (A) UV-vis spectra for ferricytochrome c (•) and its reduction by bare $\mathrm{Fe}_{3} \mathrm{O}_{4}-\mathrm{NPs}(\bullet)$; (B) An expanded scale of the $\mathrm{Q}$ band region; (C) UV-vis spectra showing the decrease in the charge-transfer absorption band due to the Fe-S(Met) bond rupture through the heme group reduction at $0 \min (\bullet), 2 \min (\bullet), 4 \min (\bullet), 6 \min (\bullet)$, and $20 \min (\bullet)$; (D) Schematic representation of the heme group in ferricytochrome c and ferrouscytochrome c; (E) VCD spectra of ferricytochrome c $(\bullet)$ and ferrouscytochrome c $(\bullet)$; (F) Deconvoluted amide I region for ferri and ferrouscytochrome c, respectively, obtained using FTIR spectroscopy. Each color indicates a different type of secondary

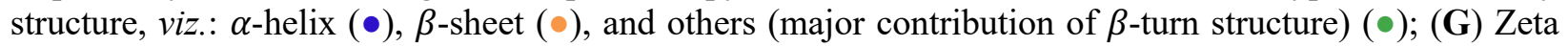
potential for $\mathrm{Fe}_{3} \mathrm{O}_{4}-\mathrm{NPs}(\bullet), \mathrm{Fe}_{3} \mathrm{O}_{4}$-NPs-Cyt c system $(\bullet)$, and ferricyt c $(\bullet)$; (H) DLS of nonadsorbed Cyt $\mathrm{c}(\bullet), \mathrm{Fe}_{3} \mathrm{O}_{4}$-NPs $(\bullet)$, and $\mathrm{Fe}_{3} \mathrm{O}_{4}$-NPs-Cyt c system (•); (I) Front and back Cyt c electrostatic potential map showing an oriented attraction between the heme group and the NP surface, while there is an oriented repulsion between the latter and the protein back side. 
After approximately $20 \mathrm{~min}$, just a small amount of Cyt $\mathrm{c}$ remained oxidized. This bond rupture leads to some extent of conformational changes surrounding the heme group, such as an increase in the Fe-N(His) bond length and the Met residue displacement responsible for an opening of the heme crevice (30) (Fig. 2D). Reported heterogeneous ET (31) involving a decaheme c-type cytochrome and $\mathrm{Fe}_{3-\mathrm{x}} \mathrm{Ti}_{\mathrm{x}} \mathrm{O}_{4}$-NPs suggests that the protein accesses the nanoparticles' superficial $\mathrm{Fe}^{2+}$, which would hint some initial mechanistic insights of $\mathrm{Fe}_{3} \mathrm{O}_{4}-\mathrm{NPs}$-ferricyt $\mathrm{c}$ interaction, as the ones shown in Fig. 2I and 3.

According to the vibrational UV circular dichroism (VCD) and infrared absorption (FTIR) measurements, protein reduction occurs without considerable changes in its secondary structure. The VCD spectrum shows a typical $\alpha$-helical band at $222 \mathrm{~nm}$ (32), which is slightly decreased when Cyt $\mathrm{c}$ is reduced (Fig. 2E, red). The spectra deconvolution shows a $4 \%$ decrease in the $\alpha$ helical content after protein reduction, which is a negligible loss of secondary content (see Table S1). In addition, although there is no indication of changes in the tertiary structure; the shift in the Soret band maximum points to an iron reduction in the heme moiety (Fig. S3). These results were corroborated by FTIR data in Fig. 2F. Table S1 brings the percentage of each secondary structure determined by deconvolution of the amide I band in the FTIR spectrum, where the reduction in $\alpha$ helical content is only $5 \%$ between ferri and ferrouscytochrome c. Therefore, one may infer that $\mathrm{Fe}_{3} \mathrm{O}_{4}$-NPs can behave as a biomimetic material of the complex III from the mitochondrial respiratory chain.

\section{Nanoparticle (NP)-protein interactions mediated by electrostatic and non-polar forces}

In order to describe the NP-protein interaction mechanism, we performed an analysis of amino acid sequences using ProtParam software (33), which indicated a net positive charge of +8 for ferricyt c. Hence, an electrostatic attraction should occur between $\mathrm{Fe}_{3} \mathrm{O}_{4}$-NPs and protein molecules, resulting in physisorption processes. Indeed, while the zeta potential for $\mathrm{Fe}_{3} \mathrm{O}_{4}-\mathrm{NPs}$ indicates a highly negatively charged surface at $\mathrm{pH} 7.4$ (Fig. 2G, blue), ferricyt c is positively charged $\left(7.5 \pm 0.6 \mathrm{mV}\right.$ ) (Fig. $2 \mathrm{G}$, red). For $\mathrm{Fe}_{3} \mathrm{O}_{4}$-NPs-Cyt c suspension, the zeta potential has an intermediate value (-26.2 $\pm 0.4 \mathrm{mV}$ ) (Fig. $2 \mathrm{G}$, black), suggesting that some of the surface charges were compensated by mutual attraction. The $\mathrm{Fe}_{3} \mathrm{O}_{4}$-NPs-Cyt $\mathrm{c}$ interaction is also evidenced by the hydrodynamic diameters from dynamic light scattering (DLS), where the three size distributions correspond to nonadsorbed protein molecules $(3 \pm 2 \mathrm{~nm})$, free $\mathrm{Fe}_{3} \mathrm{O}_{4}-\mathrm{NPs}(19 \pm 2 \mathrm{~nm})$ and a $\mathrm{Fe}_{3} \mathrm{O}_{4-}$ 
NPs-cyt c system at $51 \pm 2 \mathrm{~nm}$ (Fig. 2H). The physisorption process was studied with UV-vis spectroscopy to monitor changes in aqueous ferricyt c concentration. Within the first $10 \mathrm{~min}$, approximately $34 \%$ of the protein molecules were adsorbed by the nanoparticles (Fig. S4). The potential map for ferricyt $\mathrm{c}$ in Fig. 2I suggests that electrostatic forces govern the interaction between the NPs and the protein heme moiety since its charge distribution is inhomogeneous around the heme group. This effect induces a favorable electrostatic interaction between $\mathrm{Fe}_{3} \mathrm{O}_{4}$ NPs and ferricyt c under neutral conditions.

The interaction mechanism was further studied through the fluorescence quenching effect. When ferricyt c is excited at $300 \mathrm{~nm}$, the emission spectrum displays a strong band at $346 \mathrm{~nm}$ assigned to its single tryptophan (Trp) amino acid residue (34). Upon the addition of increasing concentrations of $\mathrm{Fe}_{3} \mathrm{O}_{4}-\mathrm{NPs}$, there is a progressive reduction in the maximum protein fluorescence (Fig. S5). The nature of the quenching mechanism was determined with experiments at 15, 25, and $35^{\circ} \mathrm{C}$ to calculate the Stern-Volmer constant $\left(K_{\text {sv }}\right)$ (Fig. S6). The plots are linear for low $\mathrm{Fe}_{3} \mathrm{O}_{4}-$ NPs concentrations, but they depart upward significantly at high concentrations. This effect supports the hypothesis of a combined dynamic and static quenching at higher NPs concentrations, while a single dynamic quenching would prevail at lower NPs concentrations (34). The $K_{\mathrm{sv}}$ values in Table S2 obtained with the linear portion of the Stern-Volmer plots in Fig. S6A show a direct correlation between the rise in temperature and NPs concentration. The bimolecular quenching constant $\left(K_{\mathrm{q}}\right)$ calculation reinforces the hypothesis that a percentage of the quencher interacts with the fluorophore through a static quenching since purely dynamic processes generally exhibit $K_{\mathrm{q}}$ maximum values around $10^{10} \mathrm{~L} \mathrm{~mol}^{-1} \mathrm{~s}^{-1}$; however, for $\mathrm{Fe}_{3} \mathrm{O}_{4}-\mathrm{NPs}-\mathrm{Cyt} \mathrm{c}$ interactions $K_{\mathrm{q}}$ is ca. $10^{11}$ $\mathrm{L} \mathrm{mol}^{-1} \mathrm{~s}^{-1}$ (Table S2). In other words, a complex is formed between $\mathrm{Fe}_{3} \mathrm{O}_{4}-\mathrm{NPs}$ and ferricyt c, which corroborates the physisorption result. With an increase in temperature, the number of binding sites per protein molecule $(n)$ and the binding constant $\left(K_{\mathrm{b}}\right)$ increase (Table 2), since heating leads to tertiary conformational changes in the protein, favoring NP-protein binding.

\section{An associative mechanism in the transition state with an enthalpy-driven process}

The kinetic characterization of ferricytochrome c reduction by $\mathrm{Fe}_{3} \mathrm{O}_{4}-\mathrm{NPs}$ was investigated using in situ UV-vis absorption spectroscopy with the experiments carried out in a pseudo-firstorder regime. Although the NPs were at least ten times more concentrated than the protein, the extent of its reduction was incomplete in all experiments. The most plausible reason for this finding 
is that the reaction equilibrium is reached before all the ferricytochrome c reacts as the redox potential difference between the $\mathrm{Fe}_{3} \mathrm{O}_{4}$-NPs and protein decreases to zero. Fig. S7A depicts the dependence of ferrouscytochrome $\mathrm{c}$ formation with time from monitoring the maximum absorbance at $550 \mathrm{~nm}$ at $25,30,35$, and $40^{\circ} \mathrm{C}$. The apparent pseudo-first-order rate constant $\left(k_{\mathrm{obs}}\right)$ and the second-order rate constant $(k)$ at various $\mathrm{T}$ were calculated (see Fig. S7B and 3A, respectively), where $k$ increases with $\mathrm{T}$, with $k=2.63 \pm 0.05 \mathrm{~L} \mathrm{~mol}^{-1} \mathrm{~s}^{-1}$ at $25^{\circ} \mathrm{C}$. As shown in Fig. $\mathrm{S} 8$ and $\mathrm{S} 9$, once in its reduced state the protein tends to re-oxidize under $\mathrm{O}_{2}$ atmosphere, but with a $k_{\text {obs }}$ ten thousand times slower $\left(k_{\text {obs }}=9.72 \times 10^{-7} \mathrm{~s}^{-1}\right)$ than $k_{\text {obs }}$ for its reduction by $\mathrm{Fe}_{3} \mathrm{O}_{4}-\mathrm{NPs}\left(k_{\mathrm{obs}}\right.$ $\left.=1.74 \times 10^{-3} \mathrm{~s}^{-1}\right)$, indicating that this re-oxidation is kinetically unfavorable.

Using these results and the Arrhenius equation, we calculated the protein reduction activation energy ( $E_{a}$ ), which is $40.2 \pm 1.5 \mathrm{~kJ} \mathrm{~mol}^{-1}$ (Fig. 3B). Detailed information on the reaction mechanism was obtained by calculating the activation parameters (Fig. S10) (35), including enthalpy of activation $\left(\Delta H^{*}=+37.9 \pm 1.5 \mathrm{~kJ} \mathrm{~mol}^{-1}\right)$ and entropy of activation $\left(\Delta S^{\ddagger}=-109 \pm 6.34 \mathrm{~J}\right.$ $\mathrm{mol}^{-1} \mathrm{~K}^{-1}$ ). Near room temperature, $\mathrm{E}_{\mathrm{a}}$ is ca. $2.5 \mathrm{~kJ} \mathrm{~mol}^{-1}$ larger than $\Delta H^{\ddagger}$, which was close to what we have observed. $\Delta S^{\ddagger}$ is particularly large and negative, as is often the case for a second-order reaction via a bimolecular step. The entropy decrease is related to the associative mechanism with the two reactants species converging into a single transition state (36). Thermodynamic parameters such as free energy of binding ( $\Delta G^{\mathrm{o}}$ binding), enthalpy $\left(\Delta H^{\circ}\right)$, and entropy $\left(\Delta S^{\circ}\right)$ were estimated using the fluorescence measurements (Table S3). During the binding of NPs to the protein, there is a displacement of associated water molecules, which reflects in a positive $\Delta S^{\mathrm{o}}$ change of the entire system (37). Although our system is enthalpy driven - since the magnitude of $\Delta H^{\mathrm{o}}$ out-weighs those of $\Delta S^{\mathrm{o}}$ - this is an indication of both electrostatic and hydrophobic/hydrogen bonds interactions between the species (38). As shown in Table S3, $\Delta G^{\mathrm{o}}$ binding values are negative; i.e., it is a spontaneous process. Fig. $3 \mathrm{C}$ illustrates the ferricytochrome c reduction by $\mathrm{Fe}_{3} \mathrm{O}_{4}-\mathrm{NPs}$, which requires a $\Delta G^{\ddagger}$ of $+70.4 \mathrm{~kJ} \mathrm{~mol}^{-1}$ and an overall $\Delta G^{\circ}$ of $-273.6 \mathrm{~kJ} \mathrm{~mol}^{-1}$ involving the binding energy between the protein and the NPs, in addition to the electron transfer reaction itself. Therefore, the $\mathrm{Fe}_{3} \mathrm{O}_{4}$-NPs interact with ferricytochrome $\mathrm{c}$ inducing a spontaneous ET, with contributions of electrostatic binding and van der Waals/hydrogen bonds. Interestingly, this mechanism is similar to that in the mitochondrial respiratory chain between complex III and Cyt c (39). 


\section{$\gamma$ - $\mathrm{Fe}_{2} \mathrm{O}_{3}-\mathrm{NPs}$ as a biomimetic complex IV}

The intrinsic peroxidase-like activity of $\mathrm{Fe}_{3} \mathrm{O}_{4}-\mathrm{NPs}$ is well known (40), with $\mathrm{Fe}^{2+}$ ions in their crystalline structure playing a dominant role in their activity. Hence, the enzyme mimetic activity from the nanoparticles should increase with the proportion of $\mathrm{Fe}^{2+}$ ions. We performed experiments with bare $\gamma-\mathrm{Fe}_{2} \mathrm{O}_{3}$-NPs (Fig. S11) (41) to investigate the roles of $\mathrm{Fe}^{2+}$ and $\mathrm{Fe}^{3+}$ ions in the redox activity. Fig. 3D shows two sets of measurements under the same experimental conditions, with $\mathrm{Fe}_{3} \mathrm{O}_{4}-\mathrm{NPs}$ (red line) and $\gamma-\mathrm{Fe}_{2} \mathrm{O}_{3}-\mathrm{NPs}$ (green line) in the presence of ferricytochrome c. Ferricytochrome c was reduced while reacting with $\mathrm{Fe}_{3} \mathrm{O}_{4}-\mathrm{NPs}_{\text {s }}$ In contrast, $\gamma$ $\mathrm{Fe}_{2} \mathrm{O}_{3}$-NPs do not exhibit reducing activity towards the protein (that remained oxidized), as indicated by the $\mathrm{Q}$ bands spectra at 0 min (black line) and 15 min (red line) after contact between the species (Fig. S12). Therefore, the redox activity of bare $\mathrm{Fe}_{3} \mathrm{O}_{4}-\mathrm{NPs}$ requires $\mathrm{Fe}^{2+}$ ions on their surface, being oxidized by ferricytochrome c to generate a new $\mathrm{Fe}^{3+}$-enriched surface.

As previously mentioned, a different redox behavior was observed with $\gamma$ - $\mathrm{Fe}_{2} \mathrm{O}_{3}-\mathrm{NPs}$. After approximately $30 \mathrm{~min}$ in the presence of these NPs, most of ferrouscytochrome c was oxidized to ferricytochrome $\mathrm{c}$ with $k_{\mathrm{obs}}=1.1 \times 10^{-4} \mathrm{~s}^{-1}$ (Fig. S13). This behavior was shown by a progressive disappearance of the absorption bands at 520 and $550 \mathrm{~nm}$ (blue lines), in addition to a small, single band at $530 \mathrm{~nm}$ (red lines) (Fig. 3E) and a progressive appearance of a band at 700 $\mathrm{nm}$ assigned to the Fe-S(Met) bond (see Fig. S14). In this case, an increase in superficial $\mathrm{Fe}^{2+}$ concentration on $\gamma-\mathrm{Fe}_{2} \mathrm{O}_{3}$-NPs should be expected after oxidation of ferrouscytochrome c, which is the opposite behavior from the protein reduction by $\mathrm{Fe}_{3} \mathrm{O}_{4}-\mathrm{NPs}$. Therefore, we can also infer that $\gamma-\mathrm{Fe}_{2} \mathrm{O}_{3}$-NPs behave as a biomimetic material for complex IV from the mitochondrial respiratory chain. 
Fig. 3. (A) Dependence of $k_{\text {obs }}$ on the concentration of $\mathrm{Fe}_{3} \mathrm{O}_{4}$ NPs for various $\mathrm{T}: 25$ $(\bullet), 30(\bullet), 35(\bullet)$ and $40{ }^{\circ} \mathrm{C}(\bullet)$. Also indicated is $k$ calculated for each $\mathrm{T}$; (B) $\mathrm{E}_{\mathrm{a}}$ from the Arrhenius plot; (C) Schematic representation of ferricyt c (I) reduction by $\mathrm{Fe}_{3} \mathrm{O}_{4}$-NPs (II), with $\Delta G^{\ddagger}$ and $\Delta G_{\text {binding }}^{\circ}$ energies. $\Delta G^{\ddagger}$ requires Coulombic and van der Waals interactions between the species, followed by ET from the $\mathrm{NP} \mathrm{Fe}^{2+}$ sites to the protein heme group, resulting in ferrouscyt c (III) and a partially oxidized NP (IV); (D) Comparison between the redox activity of $\gamma$ $\mathrm{Fe}_{2} \mathrm{O}_{3}-\mathrm{NPs}$ and $\mathrm{Fe}_{3} \mathrm{O}_{4}-$ NPs towards ferricyt c; (E) Ferrouscyt c oxidation by $\gamma-\mathrm{Fe}_{2} \mathrm{O}_{3}-$ NPs throughout the time indicated by the fading of the bands at 520 and $550 \mathrm{~nm}$ and the appearance of one single band at $530 \mathrm{~nm}$.
A

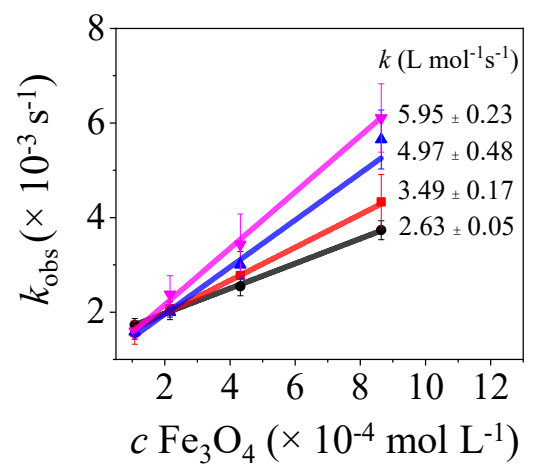

B

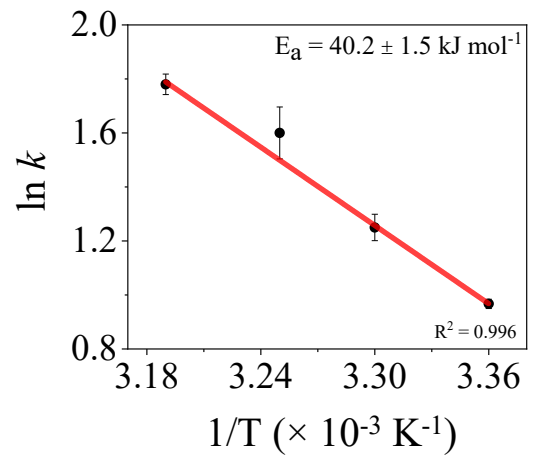

C
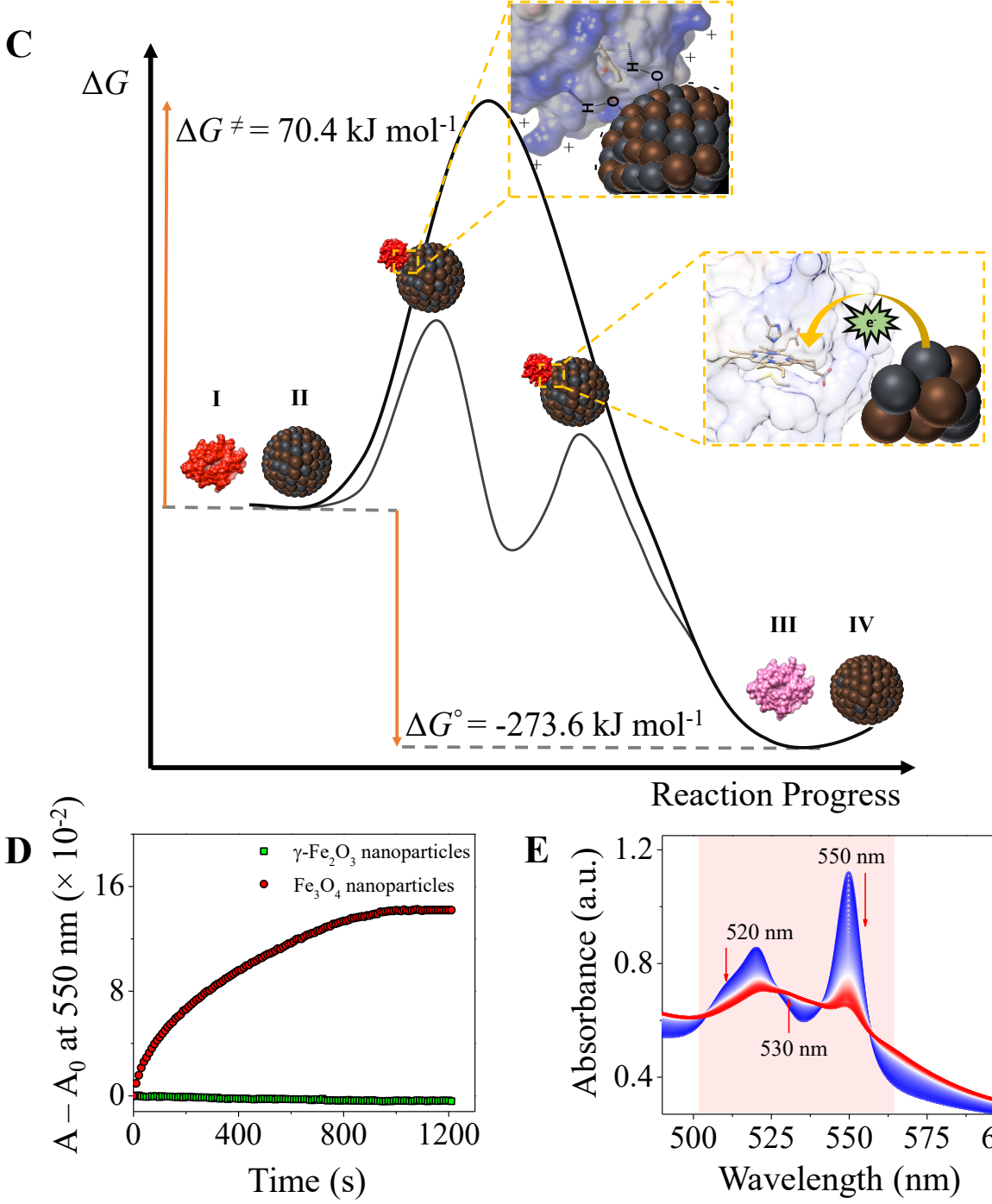

Reaction Progress



\section{NPs redox activity behavior incorporated in a mitochondrial cell membrane model}

In order to mimic the catalytic step that shows the redox activity of complex III and IV towards Cyt c, $\mathrm{Fe}_{2} \mathrm{O}_{3}$-NPs and $\gamma-\mathrm{Fe}_{2} \mathrm{O}_{3}$-NPs were incorporated in a Langmuir-Blodgett (LB) film 
employed as a simplified mitochondrial cell membrane model (see Fig. 1 and 4A). The LB film was transferred from a Langmuir monolayer made with a mixture of lipids representing the classes most frequent in eukaryotic cells, viz. phosphatidylcholines (PC), phosphatidylethanolamines (PE), and cardiolipin (CL) (42). Fig. S15 shows the surface $\pi$ - $A$ isotherms for 1,2-dipalmitoyl-snglycero-3-phosphocholine (DPPC, black), 1,2-dipalmitoyl-sn-glycero-3-phosphoethanolamine (DPPE, red), 1,1',2,2'-tetramyristoyl cardiolipin (CL, blue), and DPPC-DPPE-CL (pink) corresponding to the model membrane composition.

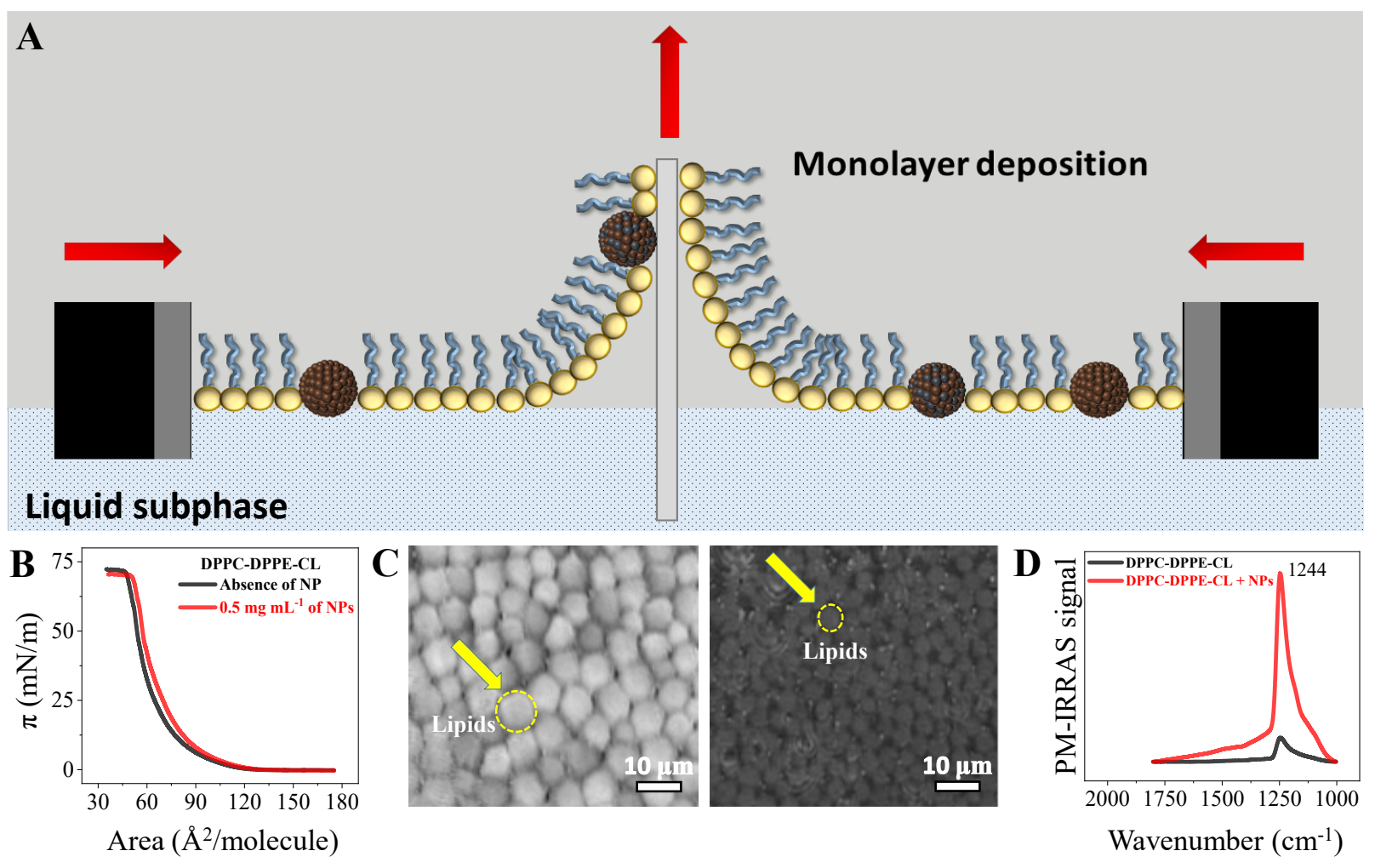

Fig. 4. Mitochondrial cell membrane model characterization. (A) Langmuir-Blodgett monolayer fabrication: the ternary lipid mixture in the presence of NPs is spread over the subphase surface and then compressed with two symmetric moving barriers to be transferred onto the supporting glass; (B) DPPCDPPE-CL monolayers in the absence $(\bullet)$ and in presence $(\bullet)$ of a $\mathrm{Fe}_{3} \mathrm{O}_{4}-\mathrm{NPs} / \gamma-\mathrm{Fe}_{2} \mathrm{O}_{3}-\mathrm{NPs}$ mixture. It should be noted that the sizes of molecules and nanoparticles are not in the same scale; (C) Zoomed BAM images of DPPC-DPPE-CL collected on PBS subphase without (left side) and with (right side) a $0.05 \mathrm{mg}$ $\mathrm{mL}^{-1}$ mixture of $\mathrm{Fe}_{3} \mathrm{O}_{4}-\mathrm{NPs} / \gamma-\mathrm{Fe}_{2} \mathrm{O}_{3}-\mathrm{NPs}$, respectively, at $30 \mathrm{mN} \mathrm{m}^{-1}$ of the monolayer compression. (D) PM-IRRAS spectra of LB films made of DPPC-DPPE-CL (•) and DPPC-DPPE-CL + a mixture of $\mathrm{Fe}_{3} \mathrm{O}_{4}-$ $\mathrm{NPs} / \gamma-\mathrm{Fe}_{2} \mathrm{O}_{3}-\mathrm{NPs}(\bullet)$ in the polar region;

The isotherm for the Langmuir monolayer of DPPC-DPPE-CL is slightly expanded by the incorporation of a mixture of $\mathrm{Fe}_{3} \mathrm{O}_{4}-\mathrm{NPs} / \gamma-\mathrm{Fe}_{2} \mathrm{O}_{3}-\mathrm{NPs}$ into the lipid chains (Fig. 4B). Such 
incorporation was confirmed by Brewster angle microscopy (BAM) images taken at four stages: at $0 \mathrm{mN} \mathrm{m}^{-1}$ (with no compression), at $18 \mathrm{mN} \mathrm{m}^{-1}$ (in the liquid-expanded phase), at $30 \mathrm{mN} \mathrm{m}^{-1}$ (corresponding to the lateral pressure of natural cell membranes), and at $60 \mathrm{mN} \mathrm{m}^{-1}$ (after monolayer collapse). Fig. S16 shows these images and zoomed pictures are shown in Fig. 4C. In the absence of NPs, the DPPC-DPPE-CL monolayer at $30 \mathrm{mN} \mathrm{m}^{-1}$ is compact and homogeneous; however, when NPs are present, this homogeneity vanishes. As the nanoparticle-containing monolayers are transferred onto solid supports in the form of LB films, a larger effect is observed according to polarization-modulation infrared reflection absorption spectroscopy (PM-IRRAS) data. Fig. 4D shows a sharp increase in intensity for the band at $1244 \mathrm{~cm}^{-1}$ assigned to $\mathrm{PO}_{2}^{-}$ asymmetric stretching (43) in the polar region. Other bands related to the polar groups are affected, as seen in Fig. S17. Furthermore, the spectra for the hydrophobic region in Fig. S18 indicate changes in the bands assigned to $\mathrm{CH}_{2}$ and $\mathrm{CH}_{3}$ stretching when comparing $\mathrm{LB}$ films with or without the mixture of $\mathrm{Fe}_{3} \mathrm{O}_{4}-\mathrm{NPs} / \gamma-\mathrm{Fe}_{2} \mathrm{O}_{3}$-NPs. Hence, the interaction of NPs with polar heads and alkyl chains affects the organization and ordering of the lipids in the model membrane, consistent with the loss of homogeneity observed in the BAM images.

The LB films were used to demonstrate the biomimetic activity of NPs as nonproteinaceous mimetic of complexes III and IV responsible for ET in the final steps of the mitochondrial respiratory chain. Electrochemical assays show no redox processes either for DPPCDPPE-CL LB film (Fig. 5A, black) or for the DPPC-DPPE-CL LB film in the presence of ferricytochrome c (Fig. 5A, red). For the latter, there is an ohmic drop since the lipid membrane partially blocks the ET between the electrode and protein. In contrast, for the LB films containing the NPs, Fig. 5A shows a well-defined quasi-reversible redox couple $\left(E^{0^{\prime}}=57.5 \mathrm{mV} v \mathrm{Ag} / \mathrm{AgCl} \mathrm{sat}_{\text {sat }}\right)$ in the presence of ferricytochrome c. This redox couple is related to $\mathrm{Fe}^{3+} / \mathrm{Fe}^{2+}$ of the heme group (44), indicating indeed that ET occurs across the lipid membrane with the aid of incorporated NPs. Additionally, results with in situ electron spectroscopy with the experimental set-up illustrated in Fig. 5B showed no redox activity for DPPC-DPPE-CL LB film towards the protein (Fig. 5C, black and red lines). However, within a few minutes, a reduction of ferricytochrome c occurs for the DPPC-DPPE-CL-NPs LB film, as seen in Fig. 5D with the expected split in the Q band. 
A
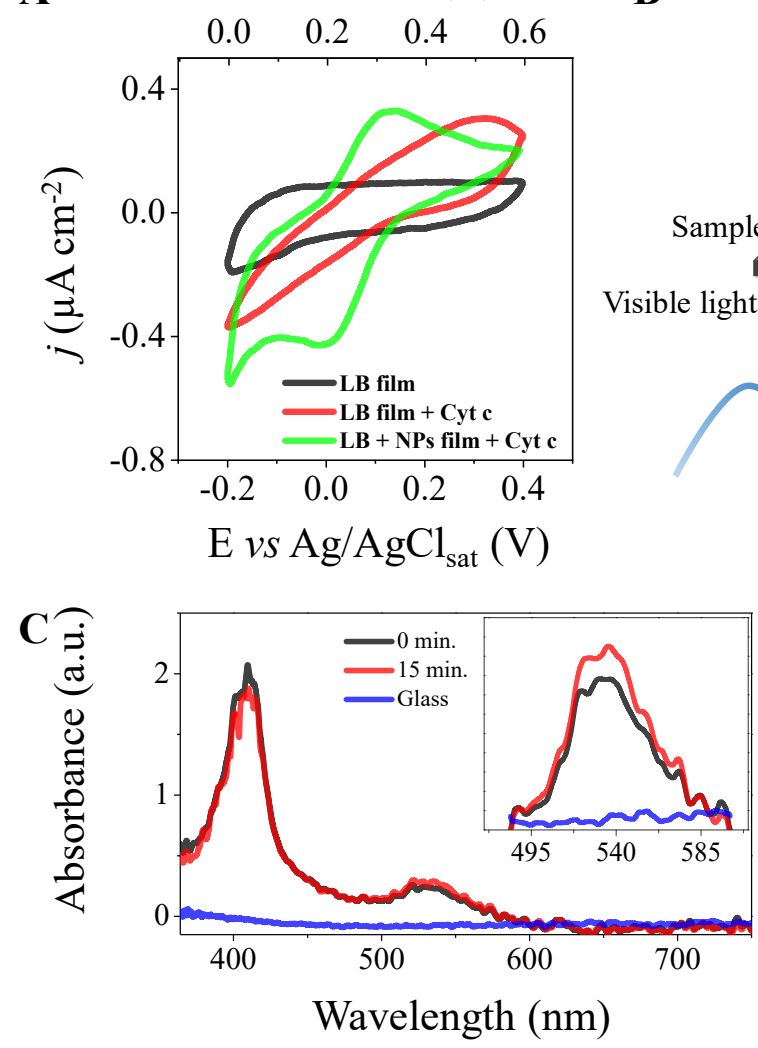

E

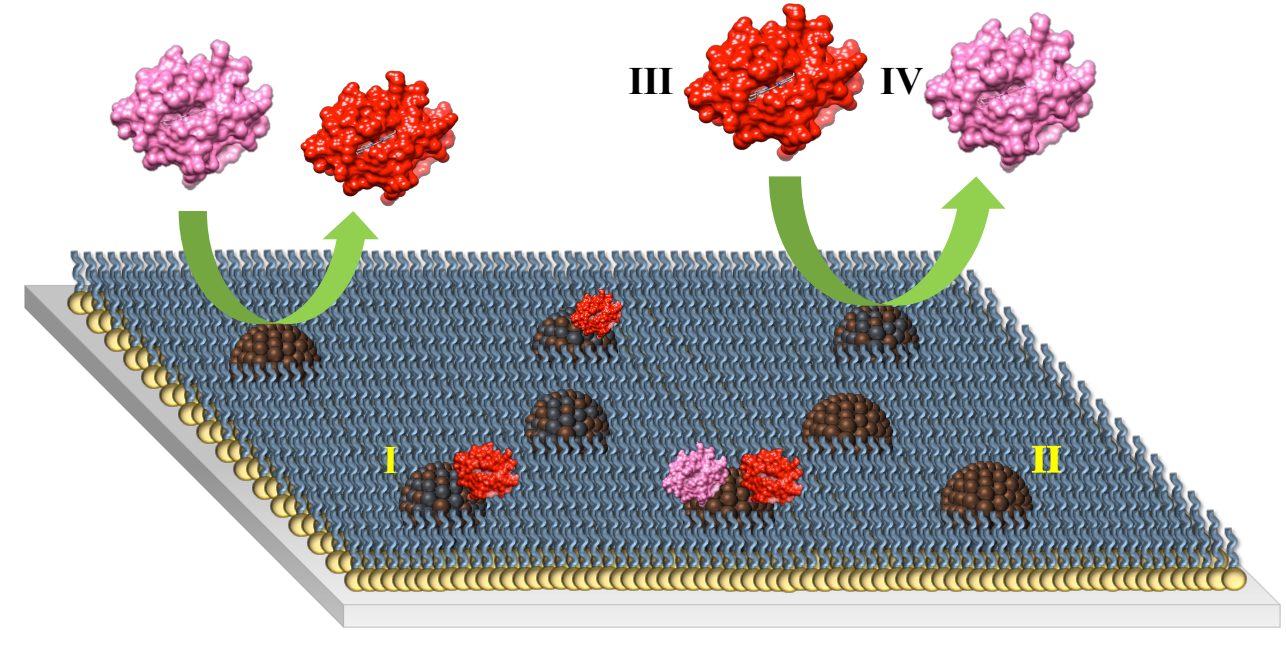

B

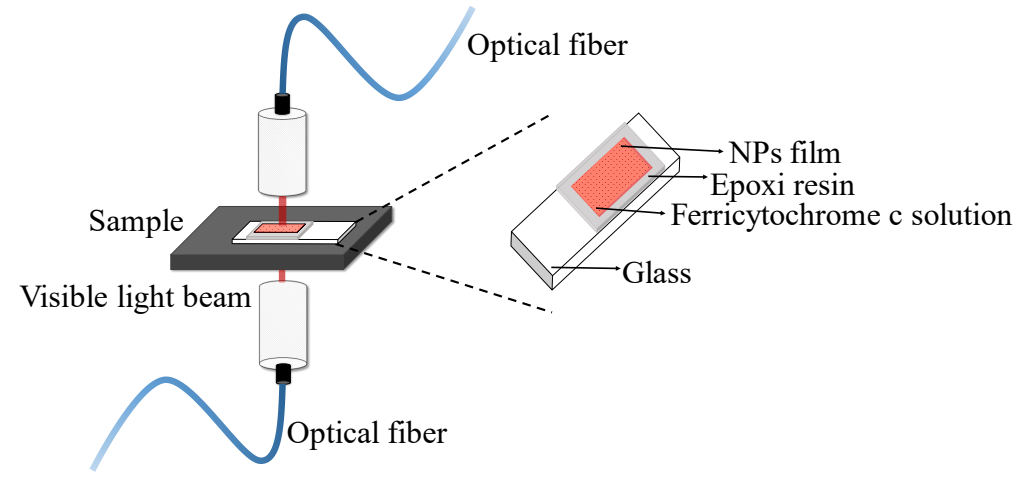


Fig. 5E illustrates the process on a nanoscopic-mesoscopic scale. As soon as the protein is added to the system, electrostatic and non-polar interactions arise. Some of the protein molecules are adsorbed onto the NPs while others just collide onto them, leading to ET processes. As the ferricytochrome c molecules interact with $\mathrm{Fe}_{3} \mathrm{O}_{4}-\mathrm{NPs}$, the content of superficial $\mathrm{Fe}^{2+}$ of NPs decrease and the protein reduces. This generates ferrouscytochrome c that interacts with $\gamma-\mathrm{Fe}_{2} \mathrm{O}_{3}$ NPs, leading to the opposite reaction, i.e., increasing the nanoparticle superficial $\mathrm{Fe}^{2+}$ content and oxidizing the protein. This process continues until the system reaches the equilibrium at $15 \mathrm{~min}$. Then, no apparent changes in the system composition occur due to the possible presence of a protective layer of Cyt c covering the NPs surface, which causes a steric hindrance to the surface access by new protein molecules.

\section{CONCLUSIONS}

We presented a molecular-level mechanistic insight of the heterogeneous electron transfer ET between nanosized iron oxides and Cyt c, in addition to the design of a bioinspired system for the mitochondrial respiratory chain. We observed direct ET between crystalline $\mathrm{Fe}_{3} \mathrm{O}_{4}-\mathrm{NPs}_{\text {s }}$ and $\gamma$ $\mathrm{Fe}_{2} \mathrm{O}_{3}$-NPs and the protein, without significant changes in its secondary and tertiary structure. The protein-nanoparticles interactions are mainly electrostatic and non-polar forces involving the heme moiety, similarly to what is observed for soluble Cyt $\mathrm{c}$ and the complexes III and IV in the respiratory chain. Kinetic and thermodynamic parameters indicated an associative mechanism in the transition state and an enthalpy-driven spontaneous reaction for the ferricytochrome c reduction. The extent of the reaction depends on the $\mathrm{Fe}^{2+} / \mathrm{Fe}^{3+}$ ratio on the surface of the nanoparticles, since superficial $\mathrm{Fe}^{2+}$ ions control ferricytochrome c reduction while ferrouscytochrome c oxidation depends on superficial $\mathrm{Fe}^{3+}$ ions. Finally, when incorporated in a lipid membrane cell model, $\mathrm{Fe}_{3} \mathrm{O}_{4}-\mathrm{NPs}$ and $\gamma-\mathrm{Fe}_{2} \mathrm{O}_{3}-\mathrm{NPs}$ maintain their redox activity, catalyzing ET similarly to complexes III and IV of the mitochondrial respiratory chain, respectively, i.e., mimicking their activity.

\section{ACKNOWLEDGMENTS}

Funding: This work was supported by the National Council for Scientific and Technological Development - CNPq (I. A. M. process 134396/2018-9), Coordinating Agency for Advanced 
Training of Graduate Personnel (CAPES) and São Paulo Research Foundation - FAPESP (L. J. A. M. process 2017/20493-2, A. R. P. process 2018/00878-0, O.N.O. processes 2017/03879-4 and F. N. C. processes 2019/15333-1 and 2019/12053-8). Author contributions: I. A. M., A. F. A. A. M., and F. N. C. conceived the project. F. N. C. and O. N. O. supervised the project. I. A. M. prepared, conceived and carried out the NPs characterization experiments, zeta potential, DLS, UV-vis, CD and fluorescence experiments. I. A. M. and L. J. A. M. conducted the FTIR and electrochemical experiments. I. A. M. and A. R. P. conducted the experiments with the mitochondrial membrane model. This manuscript was written and revised through contribution of all authors. Competing interests: Authors declare no competing interests; Data and materials availability: All data is available in the main text or the supplementary materials.

\section{REFERENCES}

1. Kumar, L. H. H. Hsu, P. Kavanagh, F. Barrière, P. N. L. Lens, L. Lapinsonnière, J. H. Lienhard, U. Schröder, X. Jiang, D. Leech, The ins and outs of microorganism-electrode electron transfer reactions. Nat. Rev. Chem. 1, 1-13 (2017).

2. H. Gong, J. Li, A. Xu, Y. Tang, W. Ji, R. Gao, S. Wang, L. Yu, C. Tian, J. Li, H. Y. Yen, S. M. Lam, G. Shui, X. Yang, Y. Sun, X. Li, M. Jia, C. Yang, B. Jiang, Z. Lou, C. V. Robinson, L. L. Wong, L. W. Guddat, F. Sun, Q. Wang, Z. Rao, An electron transfer path connects subunits of a mycobacterial respiratory supercomplex. Science 362, 1-11 (2018).

3. J. Liu, S. Chakraborty, P. Hosseinzadeh, Y. Yu, S. Tian, I. Petrik, A. Bhagi, Y. Lu, Metalloproteins containing cytochrome, iron-sulfur, or copper redox centers. Chem. Rev. 114, 4366-4369 (2014).

4. X. Wang, R. Clément, M. Roger, M. Bauzan, I. Mazurenko, A. de Poulpiquet, M. Ilbert, E. Lojou, Bacterial Respiratory Chain Diversity Reveals a Cytochrome c Oxidase Reducing O 2 at Low Overpotentials . J. Am. Chem. Soc. 141, 11093-11102 (2019).

5. V. Balasubramanian, A. Correia, H. Zhang, F. Fontana, E. Mäkilä, J. Salonen, J. Hirvonen, H. A. Santos, Biomimetic Engineering Using Cancer Cell Membranes for Designing Compartmentalized Nanoreactors with Organelle-Like Functions. Adv. Mater. 29, 1-7 (2017).

6. V. Balasubramanian, A. Poillucci, A. Correia, H. Zhang, C. Celia, H. A. Santos, Cell Membrane-Based Nanoreactor to Mimic the Bio-Compartmentalization Strategy of a Cell. ACS Biomater. Sci. Eng. 4, 1471-1478 (2018).

7. L. Otrin, N. Marušič, C. Bednarz, T. Vidaković-Koch, I. Lieberwirth, K. Landfester, K. Sundmacher, Toward Artificial Mitochondrion: Mimicking Oxidative Phosphorylation in Polymer and Hybrid Membranes. Nano Lett. 17, 6816-6821 (2017).

8. A. Byrne, J. M.; Klueglein, N.; Pearce, C.; Rosso, K. M.; Appel, E.; Kappler, Redox cycling of Fe(II) and Fe(III) in magnetite by Fe-metabolizing bacteria. Science 347, 1473-1476 (2015).

9. E. D. Melton, E. D. Swanner, S. Behrens, C. Schmidt, A. Kappler, The interplay of 
microbially mediated and abiotic reactions in the biogeochemical Fe cycle. Nat. Rev. Microbiol. 12, 797-808 (2014).

10. M. F. Hochella, S. K. Lower, P. A. Maurice, R. L. Penn, N. Sahai, D. L. Sparks, B. S. Twining, Nanominerals, mineral nanoparticles, and earth systems. Science. 319, 16311635 (2008).

11. M. F. Hochella, D. W. Mogk, J. Ranville, I. C. Allen, G. W. Luther, L. C. Marr, B. P. McGrail, M. Murayama, N. P. Qafoku, K. M. Rosso, N. Sahai, P. A. Schroeder, P. Vikesland, P. Westerhoff, Y. Yang, Natural, incidental, and engineered nanomaterials and their impacts on the Earth system. Science 363, 1-10 (2019).

12. M. Liang, X. Yan, Nanozymes: From New Concepts, Mechanisms, and Standards to Applications. Acc. Chem. Res. 52, 2190-2200 (2019).

13. A. F. A. A. Melo, G. C. Sedenho, I. Osica, K. Ariga, F. N. Crespilho, Electrochemical behavior of cytochrome c immobilized in a magnetically induced mesoporous framework. ChemElectroChem. 6, 5802-5809 (2019).

14. H. Xu, J. Chang, H. Wang, Y. Liu, X. Zhang, P. Liang, X. Huang, Enhancing direct interspecies electron transfer in syntrophic-methanogenic associations with (semi)conductive iron oxides: Effects and mechanisms. Sci. Total Environ. 695, 133876 (2019).

15. F. Yazdani, M. Seddigh, Magnetite nanoparticles synthesized by co-precipitation method: the effects of various iron anions on specifications. Mater. Chem. Phys. 184, 318-323 (2016).

16. U. Holzwarth, N. Gibson. The Scherrer equation versus the "Debye-Scherrer quation". Nat. Nanotechnol. 6, 534 (2011).

17. H. Yang, S. Yang, J. Kong, A. Dong, S. Yu, Obtaining information about protein secondary structures in aqueous solution using Fourier transform IR spectroscopy. Nat. Protoc. 10, 382-396 (2015).

18. A. Johs, L. Shi, T. Droubay, J. F. Ankner, L. Liang, Characterization of the Decaheme ctype cytochrome OmcA in solution and on hematite surfaces by small angle X-ray scattering and neutron reflectometry. Biophys. J. 98, 3035-3043 (2010).

19. Lakowicz, J. R. Quenching of Fluorescence In: Principles of Fluorescence Spectroscopy, $3^{\mathrm{a}}$ ed., Springer, USA, 2006.

20. J. S. Zhou, E. S. V. Granada, N. B. Leontis, M. A. J. Rodgers. Photoinduced electron transfer in self-associated complexes of several uroporphyrins and cytochrome c. J. Am. Chem. Soc. 112, 5074-5080 (1990)

21. M. Vincent, J. C. Brochon, F. Merola, W. Jordi, J. Gallay. Nanosecond dynamics of horse heart apocytochrome $\mathrm{c}$ in aqueous solution as studied by time-resolved fluorescence of the single tryptophan residue (Trp-59). Biochem. 27, 8752-8761 (1988).

22. Laidler, K. J. Chemical Kinetics, $3^{\text {rd }}$ ed., Pearson Education Inc., USA, 1987.

23. M. Menzinger, R. Wolfgang, The Meaning and Use of the Arrhenius Activation Energy. Angew. Chemie Int. Ed. English. 8, 438-444 (1969).

24. Y. Hu, Y. Liu, X. Shen, X. Fang, S. Qu. Studies on the interaction between 1hexylcarbamoyl-5-fluorouracil and bovine serum albumin. J. Mol. Struct. 738, 143-147 (2005).

25. I. Nurdin, M. R. Johan, I. I. Yaacob, B. C. Ang, Effect of nitric acid concentrations on synthesis and stability of maghemite nanoparticles suspension. Sci. World J. 2014, Article ID 589479 (2014). 
26. G. P. Santos, A. F. A. A. Melo, F. N. Crespilho, Magnetically controlled singlenanoparticle detection via particle-electrode collisions. Phys. Chem. Chem. Phys. 16, 8012-8018 (2014).

27. A. F. A. A. Melo, A. Hassan, L. J. A. Macedo, I. Osica, L. K. Shrestha, Q. Ji, O. N. Oliveira Jr., J. Henzie, K. Ariga, F. N. Crespilho, Microwires of Au-Ag nanocages patterned via magnetic nanoadhesives for investigating proteins using surface enhanced infrared absorption spectroscopy. ACS Appl. Mater. Interfaces 11, 18053-18061 (2019).

28. J. M. Antosiewicz, D. Shugar, UV--Vis spectroscopy of tyrosine side-groups in studies of protein structure. Part 2: selected applications. Biophys. Rev. 8, 163-177 (2016).

29. H. Z. Zhao, Q. Du, Z. S. Li, Q. Z. Yang, Mechanisms for the direct electron transfer of cytochrome c induced by multi-walled carbon nanotubes. Sensors (Switzerland). 12, 10450-10462 (2012).

30. M. W. Mara, R. G. Hadt, M. E. Reinhard, T. Kroll, H. Lim, R. W. Hartsock, R. AlonsoMori, M. Chollet, J. M. Glownia, S. Nelson, D. Sokaras, K. Kunnus, K. O. Hodgson, B. Hedman, U. Bergmann, K. J. Gaffney, E. I. Solomon, Metalloprotein entatic control of ligand-metal bonds quantified by ultrafast x-ray spectroscopy. Science 356, 1276-1280 (2017).

31. J. Liu, C. I. Pearce, C. Liu, Z. Wang, L. Shi, E. Arenholz, K. M. Rosso, Fe 3-x Ti x O 4 nanoparticles as tunable probes of microbial metal oxidation. J. Am. Chem. Soc. 135, 8896-8907 (2013).

32. S. M. Kelly, T. J. Jess, N. C. Price, How to study proteins by circular dichroism. Biochim. Biophys. Acta - Proteins Proteomics. 1751, 119-139 (2005).

33. E. Gasteiger, C. Hoogland, A. Gattiker, S. Duvaud, M. R. Wilkins, R. D. Appel, A. Bairoch, in The Proteomics Protocols Handbook, J. M. Walker, Ed. Humana Press, New York, USA, 2005.

34. Lakowicz, J. R. Quenching of Fluorescence In: Principles of Fluorescence Spectroscopy, $3^{\mathrm{a}}$ ed., Springer, USA, 2006.

35. D. A. Pixton, C. A. Petersen, A. Franke, R. Van Eldik, E. M. Garton, C. R. Andrew, Activation parameters for heme-NO binding in alcaligenes xylosoxidans cytochrome c': The putative dinitrosyl intermediate forms via a dissociative mechanism. J. Am. Chem. Soc. 131, 4846-4853 (2009).

36. Laidler, K. J. Chemical Kinetics, $3^{\text {a }}$ ed., Pearson, USA, 1987.

37. X. Du, Y. Li, Y. Xia, S. Ai, J. Liang, P. Sang, X. Ji, S. Liu, Insights into protein-ligand interactions: mechanisms, models, and methods. Int. J. Mol. Sci. 17, 144 (2016).

38. J. Yu, L. Yang, X. Liang, T. Dong, H. Liu, Bare magnetic nanoparticles as fluorescence quenchers for detection of thrombin. Analyst. 140, 4114-4120 (2015).

39. S. R. N. Solmaz, C. Hunte, Structure of complex III with bound cytochrome C in reduced state and definition of a minimal core interface for electron transfer. J. Biol. Chem. 283, 17542-17549 (2008).

40. L. Gao, J. Zhuang, L. Nie, J. Zhang, Y. Zhang, N. Gu, T. Wang, J. Feng, D. Yang, S. Perrett, X. Yan, Intrinsic peroxidase-like activity of ferromagnetic nanoparticles. Nat. Nanotechnol. 2, 577 (2007).

41. I. Nurdin, M. R. Johan, I. I. Yaacob, B. C. Ang, Effect of nitric acid concentrations on synthesis and stability of maghemite nanoparticles suspension. Sci. World J. 2014, Article ID 589479 (2014).

42. S. E. Horvath, G. Daum, Lipids of mitochondria. Prog. Lipid Res. 52, 590-614 (2013). 
43. R. Mendelsohn, G. Mao, C. R. Flach, Infrared reflection-absorption spectroscopy: Principles and applications to lipid-protein interaction in Langmuir films. Biochim. Biophys. Acta - Biomembr. 1798, 788-800 (2010).

44. R. A. S. Luz, F. N. Crespilho, Gold nanoparticle-mediated electron transfer of cytochrome c on a self-assembled surface. $R S C A d v$. 6, 62585-62593 (2016). 